\title{
IN THE SOUTH SLAVONIC GARDEN: LANDSCAPING THE LANDSCAPE OF ARGUMENTS AND NON-ARGUMENTS **
}

\section{INTRODUCTION}

Over the last couple of decades, the phenomenon of Cognate Object Construction (COC) has been extensively discussed in theoretical linguistics. Though widely discussed, even the status of the relevant nominals remains a matter of controversy. Researchers disagree not only on the syntactic and semantic status of what is referred to as Cognate Objects (COs), but also on the judgments regarding them:
(1)
a) *An uneventful life was lived by Harry.
(Jones 1988: 91)
b) A good life was lived by Susan.
(Rice 1988: 210)

In this paper, I address syntactic, semantic, and pragmatic puzzles that COs raise and also demonstrate that judgments as in (1) are not accidental or idiolectal. Rather, when viewed through the prism of languages under consideration here, they become congruent and can straightforwardly be explained.

The core of my analysis is the following. Based on the data from Serbo-Croatian (SC) and Slovene (SLO), I identify two types of COs: i) arguments (ACOs) \& ii) predicates (non-ACOs). The latter are first order predicates, while the former are arguments in the neo-Davidsonian sense. The notion of "cognatehood" is irrelevant in syntactic terms for either group, though it becomes relevant for the latter in a pragmatic sense. Syntactically, the non-ACOs are adjuncts; the fact that they cross-linguistically occur with unaccusatives is unproblematic. As for ACOs, I argue that verbs with which they appear are regular transitive and regular unergative verbs (see Marelj 2015).

The paper is organised as follows: In section 2, I present core issues that theories on COs must address. In section 3, based on SC and SLO data, I discuss CO-tests. The results of this section lead me to identify two types of COs, while in section $4 \mathrm{I}$ tackle non-ACOs and in section 5 I tackle ACOs. Finally, in section 6, I present the conclusion of this paper.

m.marelj@uu.nl

** I am grateful to the three anonymous reviewers of Linguistica for their valuable input, Marko Hladnik for the Slovene and Ora Matushansky for the Russia data. This research was partially supported by the Aspasia grant, awarded to me by the Netherlands Organisation for Scientific Research $(N W O)$, which I gratefully acknowledge here. Any errors that remain are my sole responsibility. 


\section{MYSTERIOUS MYSTERIOUSNESS}

Crosslinguistically, it is examples like (2) - featuring intransitive verbs accompanied by etymologically related nouns - that are typically found in the literature illustrating COC. The morphological relatedness is not the only characteristic of the classical cases of COs. Though there is a well-known generalisation that COs appear only with unergatives (see Hale and Keyser 2002 a.o.), it is the unaccusative die as in (3) that often crops up at the most typical example of COC.

(2) a) He dreams a dream.

b) Živi život.

lives.3sg life

'He lives a life.'

(3) a) He died a natural death.

b) Umro je prirodnom smrću.

die.prt.m.sg AUX.3sg natural death

$[\mathrm{SC}]$

'He died a natural death.'

\subsection{Scarsity of Syntactic Space}

The well-formed nature of examples such as (3) raises the question of the scarcity of syntactic space. Since the sole syntactic argument of unaccusatives (4b) begins its life as a complement of a verb, it is unclear how, to start with, "an additional complement" would enter the structure.

(4) a) $\mathrm{He}\left[{ }_{\mathrm{vP} / \mathrm{NP}}\right.$ he dreamt $]$

[Unergative]

b) $\mathrm{He}\left[\mathrm{vp}_{\mathrm{vP}}[\right.$, died he $]$

[Unaccusative]

The fact that unergatives and unaccusatives are quite different is uncontroversial. One of the tests that seems to be cross-linguistically valid pertains to the fact that the past participial can be used attributively only with the internal arguments of relevant verbs. This prediction is borne out in (5).

(5) a) the melted snow/the departed guest

b) * the shouted child

Slavonic languages behave on a par with English. For instance, a past participle in SC (active and passive alike) modifies internal arguments only (6): ${ }^{1}$

1 Under an analysis such as (4a), the question of syntactic space does not seem to arise for unegatives. However, considering the fact that the prevelant view of unergatives is rooted in Hale and Keyser's work (i), this problem arises for unergatives as well. I return to this issue in 5.2.

(i)<smiles>[Y]C([Y])NC([Y])N</smiles> 
(6) a) *plesani čovek danced man

b) razbijeni/pali andjeo

broken/fallen.prt.m.sg angel

'a broken/fallen angel'

\subsection{What's in a Modifier?}

COs do not differ only in their syntax. Smrt (death) cannot possibly occur unmodified:

(7) \#/*Umrl je smrti die.prt.m.sg AUX.3sg death

[SLO]

This behaviour is neither restricted to umreti (die) nor to SLO. However, the obligatory nature of modification does not hold in all instances of COs. This curious behaviour has been left unexplained.

\section{LANDSCAPING THE LANDSCAPE...}

As the data from SC and SLO are intended to be used as a sort of "litmus" test for the deliberation on the status of the data like (1), it is only prudent to start by submitting the relevant data to the standard tests on COs.

\subsection{Classifying Cognate Objects}

Examples in (8) - (11) represent the most canonical tests on COs. As "die" and "dream" are typically found in the literature on English, below I use their equivalents in SC and SLO as well.

(8) Passivisation:

a) San je sanjan.

Dream AUX.3sg dreamt.prt.m.sg

'The dream was dreamt.'

b) *Užasna smrt je umrna

horrible death AUX.3sg died.prt.f.sg

c) Sanje so sanjane.

dream.pl AUX.3pl dreamt.prt.f.pl

'The dreams were dreamt.'

d) *Strašna smrt je umrta

horrible death AUX.3sg died.prt.f.sg 
(9) Pronominalisation:
a) Svake noći je
sanjao
zastrašujućisan.

every night AUX.3sg dreamt.prt.m.sg terrifying dream

[SC]

'Every night he dreamt a terrifying dream.'

a') Svake noći ga je sanjao. every night CL.acc.m AUX.3sg dreamt 'Every night he dreamt it.'

b) Svake noći je umirao užasnom smrću. Every night Aux died horrible death 'Every night he died a horrible death.'

b') *Svake noći je njom umirao.

Every night AUX.3sg CL.instr.f. died.prt.m.sg.

c) Vsako noč je sanjal strašne sanje. every night AUX.3sg dreamt.prt.m.sg terrifying dream 'Every night he dreamt a terrifying dream.'

c') Vsako noč jih je sanjal. every night CL.acc.f.pl AUX.3sg dreamt 'Every night he dreamt them.'

d) Vsako noč je umrl strašne smrti. Every night AUX died.prt.m.sg horrible death 'Every night he died a horrible death.'

d') *Vsako noč jo je umrl. Every night AUX.3sg CL.gen.f died.prt.m.sg.

(10) Definiteness restriction:

a) Sanjao je taj/ovaj zastrašujući san. dreamt AUX.3sg this/that terrifying.acc dream.acc 'He dreamt that/this terrifying dream.'

b) *Umro je tom/ovom užasnom smrću. die.prt.m.sg AUX.3sg this/that horrible.instr death.instr

c) Sanjal je te/tiste strašne sanje. dreamt.prt.m.sg AUX.3sg this/that terrifying.acc dream.acc He dreamt this/that terrifying dream. 

d) *Umrl
te/tste
strašne
smrti. die.prt.m.sg AUX.3sg this/that horrible.gen death.gen

(11) Can be questioned: 2
a) $\breve{S t a}$ je
sanjao?
what AUX.3sg dream.prt.m.sg
'What did he dream?'

b) $* \check{S} t a$ je

umro?

What.ACC AUX.3SG died.prt.m.sg

c) Kaj je sanjal?

what AUX.3sg dream.prt.m.sg

'What did he dream?'
d) ${ }^{K}$ Kaj $\quad$ je
umrl?
what.acc AUX.3sg died.prt.m.sg

Based on (8) - (11), the behaviour of sanjati (dream) i umreti (die) in SC and SLO seems consistent with the behaviour of their English equivalents. The data seem to require a sort of a "hybrid" approach, since some of the COs behave like run-of-themill arguments, while others behave like non-arguments/adjuncts. Before I address the two types of COs in SC and SLO, however, I must first address the relevance of the morphological case.

\subsection{What's in a Case?}

Though (8)-(11) seem to indicate that English, on the one hand, and SC and SLO, on the other hand, pattern fully alike, this is not entirely true. The data in these morphologically robust languages seem to give rise to another generalisation; the "real" arguments appear in ACC, while the non-arguments appear in INSTR (SC) and GEN (SLO). At first blush, then, it seems that we have an additional morphosyntactic test to differentiate the argumental from the non-argumental instances of COs, thus having another piece of evidence to support that the morphological structure reflects the underlying structure. For instance, it is typically argued that non-verbal predicates bear INSTR as a predicate case (see Pereltsvaig 1999 for the discussion and references on Russian) (12).

2 I kindly ask (native) speakers of SC and SLO to grant me a bit of patience. Though they might exclaim at this point that what happens in (11b) and (11d) is an instance of a case mismatch that goes beyond the issues at stake here, I would like to remind them that leaving such examples in the text here underscores the relevance of exploring Slavonic languages like SC and SLO, since the traditional generalisation about COC in the literature (see Jones 1988, for instance) is that languages that express the morphological case overtly, such as Arabic, German, or Latin, select ACC, "a semantically empty Case to satisfy morphological requirements" (see Jones 1988: 109, but also Moltman 1989, for instance). 
(12) On stal

učitelem

$\mathrm{He}$ become.prt.m.sg teacher.instr

[Russian]

'He became a teacher.'

I argue here that a correlation between some "designated" predicate case and nonverbal predicates in South Slavonic simply does not hold. Contrary to standard views in the literature on Slavonic, I argue that there is no deeper relevance or meaning to the case marking here. The overt morphology here is simply idiosyncratic. Trivially, to begin with (quite like in other Slavonic languages), instrumental is not restricted to non-verbal predicates. For instance, verbs such as vladati (rule), upravljati (manage), dominirati (dominate) and trajati (last) in SC have INSTR internal arguments.

Not only is the correlation not two-directional, but, more importantly, it is not onedirectional either. Though there are a couple of exceptions as in (13), generally, nonverbal predicates in SC occur as NOM, not INSTR.

(13) Postao je učitelj/učiteljem

become.prt.m.sg. AUX. teacher.nom/teacher.instr

'He became a teacher.'

Slovene underscores this point about the lack of the correlation in this respect even more strongly. Firstly, the canonical cases of non-arguments under consideration here in Slovene do not even consistently appear in the same "alleged" predicate case. Rather, some are genitive (14a), while others are prepositional instrumental (14b).

$\begin{array}{lll}\text { Umrl } & \text { je naravne smrti. } \\ \text { die.prt.m.sg AUX.3sg natural death.gen } \\ \text { 'He died a natural death.' }\end{array}$
b) Rasel je $z \quad$ neustavljivo rastjo. ${ }^{3}$ grew.prt.m.sg AUX.3sg with unstoppable growth.instr 'He grew the unstoppable growth.'

Morevoer, the cases of INSTR non-verbal predicates like Russian (12) or even in $\mathrm{SC}(13)$ are always nominative. ${ }^{4}$

3 Cross-linguistically, it seems that the data on unaccusatives are met with varying reactions from native speakers. It is not obvious to me why this is so. Note that this is also the case with (14b), where R1 and my native spearker informant differ.

4 Needless to say, quite like SC, SLO also has "real" complements in genitive (ia) and prepositional instrumental case (ib):
fear.3sg CL Peter.gen
'He fears Peter.'
(i) a) Boji se Petra.
b) Upravljal je $s$ tovarno. Managed prt.m.sg AUX.3sg with factory.instr 'He managed a factory.'



(15) Postal je učitelj. became AUX.3sg teacher.nom
'He became a teacher.'

\section{ZOOMING IN ON NON-ACOS}

\subsection{Where Adverbs and Cognates Meet}

As any native speaker of SC and SLO can confirm (see also fn. 3), the ungrammaticality of (11b) and (11d) seems far more trivial than that of the English (16). INSTR- and GEN-nominals cannot be questioned using ACC $w h$-word šta/kaj (what.ACC) and whword čime (what.INSTR)/česa are required.

(16) *What did he die?

(Massam 1990:164)

Note importantly, however, that the use of the morphologically "appropriate" whword will not improve the grammaticality of SLO and SC examples (17).
$\begin{array}{clll}\text { a) *Čime } \quad \text { je } & \text { umro? } & \text { Užasnom smrću. } \\ \text { what.instr AUX.3sg } & \text { die.prt.m.sg } & \text { terrible.instr death.instr }\end{array}$
b) *Česa je umrl? Strašne smrti. what.gen AUX.3SG die.prt.m.sg horrible.gen death.gen

The way to question the relevant SC and SLO examples is by using the $w h$-word "how":

(18)
Kako je
umro?
Užasnom smrću.

$[\mathrm{SC}]$

'How did he die? A horrible death.'

What does the use of this $w h$-element tell us about the syntax and semantics of nonACOs? Wh-word kako (how) appears with adverbial modification - specifically, with manner adverbs. Consequently, interpretatively, non-ACOs seem to be comparable to manner adverbs (19).

(19) Kako se ponaša? Pristojno/loše... how CL behave.3sg decently/badly

'How does he behave? Decently/badly....'

The fact that examples such as (20a) can be paraphrased using sentences like (20b) further underscores the parallelism: 
(20) a) Smejao se grohotnim smehom. laugh.prt.m.sg CL loud.instr laugher.instr

'He laughed a loud laughter.'

b) Grohotno se smejao.

loudly CL laugh.prt.m.sg

'He laughed loudly.'

The question that now arises is the following: How should this parallelism be understood and formalised?

\subsection{On Adverbs and Analogies}

Since we have noted the parallelism between manner adverbs and non-ACOs, we can explore whether or not an approach to the latter can be modelled based on the established approach to the former.

The most elegant approach to manner adverbs originates in Davidson (1967). In Davidson's original proposal, the event argument is accommodated by analysing the predicate as having one more argument place than is assumed in traditional analyses. The event argument (e) is existentially quantified, with the result that a sentence like (21a) takes on a logical structure, such as in (21b). Manner adverbs are added conjunctively and predicate the event argument directly, as in (21c).

(21) a) Tristram ate a snowflake (carefully).

b) $\exists$ e eat (Tristram, a snowflake, e)

c) $\exists$ e $[\operatorname{EAT}(\mathrm{e}, \mathrm{T}, \mathrm{s}) \&$ carefully (e)]

The neo-Davidsonian tradition (Higginbotham 1987, Parsons 1990) deviates from the original arguments into separate conjuncts as well:

(22) $\exists$ e [ working (e) \& Agent (e) $=\mathrm{T} \&$ Theme (e) $=$ s \& carefully (e)]

The status of event argument modifiers seems to be exactly the right "description" of what non-ACOs in SC and SLO do. Indeed, my hypothesis is that the non-ACOs in SC and SLO are event predicates. ${ }^{5}$ Let us explore this hypothesis further.

\subsection{Referentiality, or One More Look at the Pronominalisation Test}

Predicates are non-referential. For nominal predicates, this typically means that they are indefinite (see Higginbotham 1987 a.o.). Cannonical cases that illustrate this include the bare NPs in languages like Dutch, which appear in predicative, but are barred from the argument positions. Though using bare NPs will not be a test in SC

5 See Moltmann (1989) for the same conclusion regarding English and German COs of verbs like "die". 
and SLO, using pronominalisation as a test is a good way to establish the semantic status of a nominal. ${ }^{6}$

The rationale is straightforward: pronouns canonically refer to individuals and not to properties. Arguments always have referents and, consequently, can be pronominalised. Predicates do not have referents and hence cannot be pronominalised (23).

(23)
a) Postao je matematičar $/ *$ on
[primary predicate] became.prt.m.sg AUX mathematician/he 'He became a mathematician/*he'
b) Smatraju Mariju lepoticom/*njome [secondary predicate] consider.3.pl Marija.acc beauty.instr/her.instr 'They consider Maria a beauty, ${ }^{*}$ her'

Note now that the non-ACOs behave on a par with the predicates (24) and quite unlike the regular arguments (25) with respect to pronominalisation (recall also (9) please) and (impersonal) passivisation (recall also (8) please).
(24) a) Nasmejao
se grohotnim smehom/*njim.
[INSTR-non-ACO] laughed.prt.m.sg CL loud laugher.instr/him.instr 'He laughed a loud laughter/*it.'
b) *Grohotnim smehom je/se nasmejalo. loud laughter.instr AUX/CL laughed.prt.n.sg
(25) a) On upravlja fabrikom/njom. he manage.3SG factory/it-INSTR 'He manages a factory/it.'
b) Fabrikom je upravljano (od strane radnika). factory.instr AUX managed prt.n.sg (by the workers) 'The factory was managed by the workers.'

In what follows, I demonstrate how two important properties of non-ACOs (see section 2) follow from the simple hypothesis that non-ACOs are event predicates.

\section{4 Mystery of Modification}

The modification of non-ACOs need not always be appositive (26), but must always be present. The data below are from SC, but this is cross-linguistically true.

6 There is a known caveat here; it has been long established that there are pronouns the denotation of which is a property, rather than an individual (see Jespersen 1927; Williams 1983, a.o.), but [+human] pronouns are restricted to individuals. 

(26) Umro je smrću mučenika. die.prt.m.3sg AUX.3sg death.instr martyr.gen 'He died a martyr's death'

Though sentences like (7) are typically marked as ungrammatical in the literature, my assumption is that there is nothing wrong with their structure. I argue that they are pragmatically odd and that this oddness is the result of an interplay between their semantic status as predicates and their cognatehood.

The relevant questions are the following:

a) Is it relevant for grammar as such that non-ACOs are etymologically related to relevant verbs or is this relatedness an idiosyncratic feature with no relevance whatsoever?

b) Why is the modification of ACOs obligatory?

My hypothesis is that these two questions are directly related. Namely, I only partially agree with Perelsvaig's (Perelsvaig 1999) conclusion that cognatehood is completely and fully irrelevant and inconsequential. Specifically, I concur with her conclusion that relatedness of relevant nominals is irrelevant in the cases of ACOs, the structural position and the denotation of which are no different than those of run-ofthe-mill complements unrelated to the relevant verb. I argue, however, that the same rationale does not hold for non-ACOs. Their cognatehood becomes relevant since, in the absence of a modifier, an utterance like (27a) becomes pragmatically infelicitous, as it violates the Gricean Maxim of Quantity.

(27) a) \#Tristram died a death.

b) Tristram died a horrible death.

Just like manner modifiers, non-ACOs predicate the event argument directly. In the absence of the modifier, however, this result is uninformative, since the primary predicate (verb) and the secondary predicate (nominal) are identical (28a). ${ }^{7}$ The relevant part of the sentence that tells us how the event of dying is happening - be it "naturally" or "horribly" - rests on the modifier, not the nominal predicate (28b).

(28) a) \#Tristram je umro smrću.

a') $\exists$ e [ dying(e, T) \& death (e)]

b) Tristram je umro užasnom smrću.

b') $\exists$ e [ dying(e,T) \& horrible death(e)]

7 My use of the notion «cognatehood» should be taken as a very crude shorthand. Lack of space prevents me from further discussing this, but rather than morphological or etymological relatedness, «identical» here should be understood roughly as «something that is presupposed» by the primary predicate. This is the reason why \#Opomenuo je glasom/He warned her in a voice is infelicitous, whereas Opomenuo je tihim glasom/He warned her in a soft voice is fine. 


\subsection{Scarcity of Syntactic Space Revisited}

Being modifiers, non-ACOs are expected to be adjuncts. This is a desireable outcome, as they cross-linguistically occur with unaccusatives.

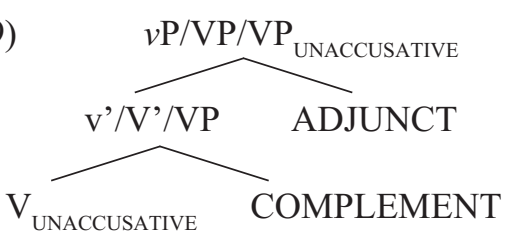

It is completely irrelevant for the purposes of our discussion here if we think of an adjunct as a sister to V', under the direct dominance of VP and the linearisation of which is different from that of arguments or if we treat them as creatures that involve a different plane altogether. Importantly, syntactically, the position that non-ACOs occupy is never that of internal arguments. ${ }^{8}$

\section{ZOOMING IN ON ACOS}

\subsection{True Complements}

Quite like regular complements, ACOs occur with strong determiners, like (30) for instance, and pass other tests other run-of-the-mill arguments do as well (recall (8) $-(11))$.

(30) Sanjal

je vse sanje (ki so kdaj obstajale). dream.prt.m.3sg AUX.3sg every dream.acc (that every existed)

[SLO] 'He dreamt every dream (that every existed)'

\subsection{The Syntax of ACOs}

So far, we have established that ACOs behave like regular complements. The question that arises now is: What is their syntactic structure? Since the dominant analysis of unergatives is the one developed by Hale and Keyser (Hale and Keyser 1993 et seq.), according to which the relevant unergatives involve a process of incorporation (31), this questions is far from trivial.

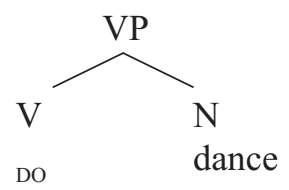

8 (29), even as a simplification, is not the only possible structure, but for the purposes of our discussion, it is sufficient. 
Namely, if their analysis is correct, then there is no syntactic space for the ACO as the bare noun already occupies the position of the object. Hale and Keyser (1997) offer to solve this problem by using "index deletion", which allows the trace left by the incorporation of dance into the semantically empty verb DO to be obliterated (invisible to syntax and interpretation). The process of the index deletion then allows the cognate object to be generated in the base position of the bare noun. For general theoretical reasons, this is not an optimal solution (see also Hale and Keyser 2002).

Hale and Keyser (2002) modify the account of Hale and Keyser (1997) by splitting the group of cognate objects into those that are "zero-related" and those that do not share a root with the relevant verb, then arguing that only the former, but crucially not the latter, are the results of their incorporation mechanism. Under this account, then, one could expect "dance a dance" and "dance a Mazurka" to have different syntactic structures and "derivational history". Only in the latter case could the verb "dance" be directly generated as a "fully-fledged" verb. Something like "dance a dance" should behave like an incorporation, whereas "dance a Mazurka" should behave like a regular transitive verb. However, if put through the standard tests (as those illustrated in (8) - (11)), the two behave completely on a par. Furthermore, this theory provides no explanation as to why the verb "dance" would not be able to be directly generated in the position of the verb in the "zero-related" cases to begin with.

Morevoer, one might say that the behaviour of the proverbial "die a gruesome death" and "smile a silly smile" actually argues against incorporation analysis for COs even more strongly than other pieces of data do.

Discourse referentiality (32) is typically taken to be a diagnostic of $\mathrm{N}($ oun) I(ncoproration) as a syntactic phenomenon:

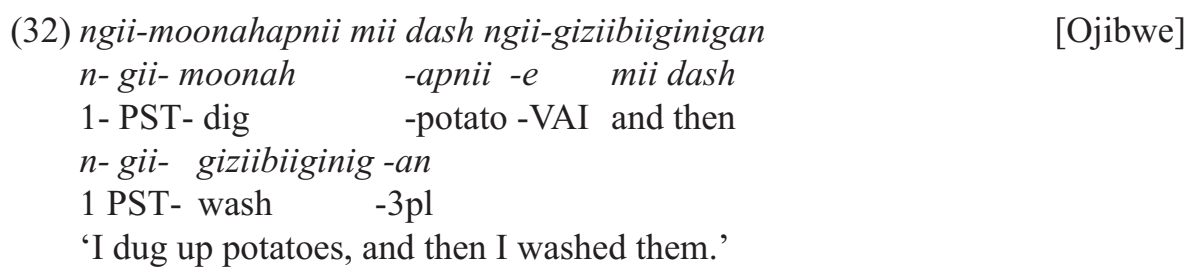

(BJ, 2008-12-17, cited in Barrie \& Matheu 2015:4)

However, if discourse referentiality is characteristic of NI, then non-ACOs clearly do not seem to behave like NIs, as they are never referential (recall (9)) and consequently cannot be picked up in subsequent discourse (33):

(33) a. *He smiled a happy smile and then her son smiled it too.

An alternative to incorporation analyses is a transitive structure such as (34) (see also Pereltsvaig 1999). ${ }^{9}$

9 In this respect, the difference between Pereltsvaig 1999 and my account is that I argue that there is a subset of verbs that take ACOs but which are primitively unergative (see Marelj 2015 for discussion). 


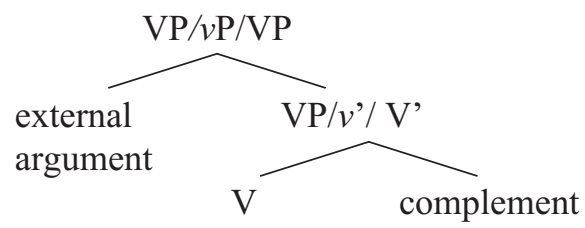

\subsection{The Relevance of the Semantic Status of ACOs?}

The reason we see the restriction in the examples in (36), but not in the examples in (35), is that the two types of nominal phrases are completely different semantically. Whereas non-ACOs are discussed in the previous section, 4.3 focuses on ACOs.

$$
\begin{aligned}
& \text { (35) Pleše ples. } \\
& \text { dance.3sg dance } \\
& \text { 'S(he) dances a dance.' } \\
& \text { (36) \#Smeje se smehom. } \\
& \text { laugh.3sg CL laugh } \\
& \text { '\#He laughed a laugh.' }
\end{aligned}
$$

Under a neo-Davidsonian view, thematic roles describe the way a participant takes part in an event. Unlike predicates, arguments then relate to an event indirectly - via thematic roles (37): ${ }^{10}$

(37) a) Luka priča pravilno. Luka talk.3sg correctly c) $\exists$ e [talking (e) \& Agent (e, Luka) \& correctly(e)]

That the relation is mediated through a thematic role renders utterances in which ACOs appear always informative enough, regardless of whether ACOs are cognate or not. ${ }^{11}$ Hence, no modification of these arguments is required.

Indeed, verbs that allow both ACOs and non-ACOs require modification only in the cases of non-ACOs:
(38) Luka živi
život
/životom fudbalera
/\#živi životom.
Luka live.3sg life-acc /life.instr footballer.gen /\# live. life.instr

10 For ease of exposition, temporal information is absent from semantic formulae throughout.

11 "Informative enough" must here be understood against the background of the Neo-Davidsonian (specifically Parsons 1990) understanding of what the verb meaning is. Verbs denote one-place predicates of events and thematic roles are functions from events divided into individuals/participants of events. The 'labels' like Agent, Theme, Sentient inform us about the kind of involvement/the nature of the participation of an individual in the event under consideration. 
Last but not least, in accordance with the hypothesis that ACOs and non-ACOs are different, note that they can also co-occur as in (39) from SC: ${ }^{12}$

(39) (Posle dijagnoze raka).... odlučila je da [živi život] [životom filmske zvezde] decided.prt.f.3sg AUX.3sg that live.3sg life.acc life.instr film star.gen

'(After the cancer diagnosis)...

she decided to live a life of a movie star.'

\subsection{Making Sense of Diametrically Opposed Judgments}

As evident from (38) and (39), some verbs can take both ACOs and non-ACOs. Within this analysis, one expects that ACOs of such verbs behave like regular arguments, while their non-ACOs are expected to behave like predicates. These predictions are borne out. As illustrated in (40a), for instance, while an ACO can appear with a strong determiner, a non-ACO (40b) cannot:
a) Sanjao
je svaki san
(kojijeikadapostojao). [Argument] dream.prt.m.sg AUX every dream.acc (that ever existed) 'He dreamt every dream that ever existed.'
b) *Sanjao je svakim snom (kojije ikada postojao).[Predicate] dream.prt.m.sg AUX every dream.instr (that ever existed)

The existence of data like (38) - (40) leads me to propose that quite like SC, English also has verbs that allow either ACOs or non-ACOs and that different judgements reflect these different options. While English lacks the initial "morphological clues" that one might be dealing with in two different types of nominals, under the relevant tests like e.g. passivisation, the data in English start behaving quite like the morphologically "robust" languages. ${ }^{13}$

12 As emphasised by R1, SLO behaves differently than SC here, as the counterpart of SC (39) is ungrammatical. What is interesting to note here is that it is not only the case that SLO disallows the co-occurrence of relevant ACOs and non-ACOs with verbs like dream or live, but also that it does not allow non-ACOs to appear with these verbs at all. It is not obvious why this is the case, but note that SLO has only a prepositional instrumental and its use is somewhat more restricted that in related languages. This seems to be relevant since the counterpart in Russian, for instance, is perfectly fine.
(i) Ona prožila
žisn'
žisn'ju
spuerzvezdy
She live.prf.dur
life.acc
life.instr
superstar.gen

13 The poverty of the morphological case system in English is arguably also responsible for the inability of the two types of COs to co-occur together, giving rise to, for instance, a counterpart of (39) in English. 


\section{CONCLUSION}

In this paper, I dealt with the phenomenon of cognate objects, viewed particularly through the prism of Serbo-Croatian and Slovene. The upshot of this analysis is that there are two types of COs: cognate arguments (ACOs) and cognate predicates (nonACOs). The notion of "cognatehood" becomes relevant in the case of non-ACOs; their modification is required if utterances in which they appear are to be pragmatically felicitous. As far as ACOs are concerned, because the relation between an ACO nominal and the event variable is always mediated through a thematic role, utterances in which they occur are always informative enough. No modification of ACOs is required and their "cognatehood" is incosequential. The status of non-ACOs as adjuncts makes the syntax of unaccusatives with which they are licensed uproblematic. As for ACOs, I argue that some of the verbs with which they occur are primitively transitive, while others are primitively unergative. Crucially, there does not seem to be good reason to treat either ACOs or non-ACOs as incorporations. An examination of morphologically robust languages such as SC and SLO facilitates an understanding of some of the puzzling properties of COCs cross-linguistically and also offers a means of explaining the disagreement regarding the judgments found in languages like English.

\section{References}

BARRIE, Michael/Eric MATHIEU (2015) "Noun Incorporation and Phrasal Movement." Natural Language and Linguistic Theory 34/1, 1-51.

DAVIDSON, Donald 1967. "Truth and Meaning." In: D. Davidson (ed.), Inquiries into Truth and Interpretation. Oxford: Claredon Press, 17-36.

HALE, Ken/Samuel Jay KEYSER (1993) "On Argument Structure and Lexical Expression of Syntactic Relations." In: K. Hale/S. J. Keyser (eds), The View from Building 20: Essays in Linguistics in Honor of Sylvain Brombeger. Cambridge, Mass: MIT Press, 53-110.

HALE, Ken/Samuel Jay KEYSER (1997) "On the Complex Nature of Simple Predicators.” In: A. Alsina/J. Bresnan/P. Sells (eds), Complex Predicates. Standford: CSLI Publications, 29-66.

HALE, Ken/Samuel Jay KEYSER (2002) Prolegomenon to a Theory of Argument Structure. Cambridge, Mass: MIT Press.

HIGGINBOTHAM, Jim (1987) “Indefiniteness and Predication.” In: E. Reuland/A. ter Meulen (eds) The Representation of (In) definiteness. Cambridge, Mass: MIT Press, 43-70.

JONES, Michael Allen (1988) "Cognate Objects and the Case-Filter." Journal of Linguistics 24, 89-110.

JESPERSEN, Otto (1927) A Modern English Grammar on Historical Principles, Volume III (Syntax). København: Munksgaard. [Reprinted by Allen \& Unwin 1954.]

MARELJ, Marijana (2015) On Arguments and Predicates: In the Realm of COs. Paper presented at FDSL 11, University of Potsdam. 
MOLTMANN, Friederike (1989) "Nominal and Clausal Event Predicates." In: Papers from the $25^{\text {th }}$ Annual Regional Meetings of the Chicago Linguistic Society, 300-314. University of Chicago.

PARSONS, Terence (1990) Events in the Semantics of English: A study in Sub-Atomic Semantics. Current Studies in Linguistics Series 21. Cambridge, Mass: MIT Press. PERELTSVAIG, Asya (1999) "Cognate Objects in Russian: Is the Notion "Cognate" Relevant for Syntax?" Canadian Journal of Linguistics 44/3, 267-291.

RICE, Sally (1988) "Unlikely Lexical Entries.” In: Proceedings of the Fourteenth Annual Meeting of the Berkeley Linguistics Society, 202-212.

WILLIAMS, Edwin S. (1983) "Semantic vs. Syntactic Categories." Linguistics and Philosophy 6, 423-446.

Summary

IN THE SOUTH SLAVONIC GARDEN: LANDSCAPING THE LANDSCAPE OF ARGUMENTS AND NON-ARGUMENTS

This paper deals with morphological, syntactic, semantic, and pragmatic aspects of the so-called Cognate Object Construction with particular reference to Serbo-Croatian and Slovene. The relevance of an examination of such morphologically robust languages is manifold. It facilitates an understanding of some of the puzzling properties of the construction cross-linguistically, offers a way of explaining the noted disagreement regarding judgments found in the literature on Germanic languages such as English and also presents a clear case where (contrary to the dominant view in the literature) morphology seems to deceive, rather than inform us, about syntax. Based on a barrage of tests, I argue that there are two types of cognate objects: arguments and non-arguments. Extending the treatment of modifiers within the Davidsonian tradition to the latter, I analyse them as first-order predicates. This allows me to capture their core properties, among which is the obligatory modification, something unaccounted for in the literature. The semantic parallelism between the adverbial modifiers and non-ACOs extends to the syntax as well. Treating non-ACOs as adjuncts solves the problem of the scarcity of syntactic space that arises with unaccusative verbs that license them. ACOs, on the other hand, behave syntactically and semantically like run-of-the-mill arguments and a run-of-the-mill transitive syntax can be maintained (for a majority of them) instead.

Keywords: argument, cognate, predicate, unaccusative, unergative

Povzetek

V JUŽNOSLOVANSKEM VRTU: RISANJE POKRAJINE GLAGOLSKIH ARGUMENTOV IN NE-ARGUMENTOV

Članek obravnava morfološke, skladenjske, pomenske in pragmatične vidike t.i. zgradb s tavtološkimi predmeti s posebnim poudarkom na srbohrvaškem in slovenskem 
jeziku. Obravnava morfološko bogatih jezikov je pomembna iz več razlogov. Omogoča namreč razumevanje nekaterih zapletenih lastnosti teh zgradb v več jezikih, ponudi način, kako razložiti znana razhajanja pri sodbah, ki jih najdemo v literaturi o germanskih jezikih (kot je npr. angleščina), ter služi kot jasen zgled, kako je morfologija lahko bolj zavajajoča kot informativna glede skladnje (proti prevladujočemu mnenju v literaturi). V članku na osnovi številnih testov zagovarjam trditev, da obstajata dva tipa tavtoloških predmetov, argumentni in neargumentni. $Z$ razširitvijo obravnave modifikatorjev znotraj davidsonske tradicije na neargumente, so le-ti obravnavani kot predikati prvega reda. Ta pristop omogoča razlago njihovih temeljnih značilnosti, kot je npr. obvezna prisotnost prilastka. Pomenske vzporednice med prislovnimi določili in neargumentnimi tavtološkimi predmeti je mogoče razširiti na skladnjo. Obravnava neargumentnih tavtoloških predmetov kot prislovnih določil namreč reši problem pomanjkanja skladenjskega prostora, ki se pojavi pri netožilniških glagolih. V nasprotju z neargumentnimi tavtološkimi premeti pa se argumentni tavtološki predmeti obnašajo kot običajni argumenti z običajno skladnjo glede glagolske prehodnosti.

Ključne besede: glagoski argument, tavtološki predmet, predikat, netožilniški glagol, neergativni glagoli 